\title{
Consumer acceptability and salt perception of food with a reduced sodium content
}

\author{
Mariloux Malherbe, Corinna M Walsh and Cay A van der Merwe
}

\begin{abstract}
OPSOMMING
Die doel van die studie was om te bepaal tot watter mate die soutinhoud van voedsel verlaag kan word, sonder om ' $n$ betekenisvolle verandering in die aanvaarbaarheid en soutpersepsie van 'n reeks tuisvoorbereide voedsels te veroorsaak.
\end{abstract}

' $n$ Verteenwoordigende steekproef van die stedelike populasie in die Vrystaat $(\mathrm{N}=58)$ is gebruik, met ouderdom en ras as voorspellers. Affektiewe sintuiglike toetse is gebruik om die aanvaarbaarheid en soutpersepsie van vier geregte met variërende natriumkonsentrasies (normale natriuminhoud; ongeveer een derde natriumverlaging en ongeveer twee derdes natriumverlaging) vas te stel. Die natriuminhoud is bepaal met behulp van voedselsamestellingstabelle en is bevestig met behulp van chemiese analise.

' $n$ Herhaalde metings/multi-faktore ANOVA is gebruik vir data-analise en gepaarde t-toetse is aangewend om te toets vir beduidende verskille tussen die gemiddeldes.

Die verskil in gemiddelde aanvaarbaarheid van die normale resep en die 1/3 natriumverminderde resep vir die saamgestelde gereg met ' $n$ gladde tekstuur (groentesop) was nie betekenisvol nie $(p=0,59)$. Dieselfde bevinding is gemaak ten opsigte van die eenvoudige gereg met ' $n$ growwe tekstuur (krummelpap, $p=0,14$ ) en die saamgestelde gereg met ' $n$ growwe tekstuur (beesvleisbredie, $p=0,47$ ). In teenstelling het die $1 / 3$ natriumverlaging van die eenvoudige gereg met ' $n$ gladde tekstuur (kapokaartappels) die aanvaarbaarheid betekenisvol beïnvloed $(p \leq 0,0001)$. In teenstelling met aanvaarbaarheid, is soutpersepsie afhanklik van die voedsel wat as draer gebruik word, sowel as kruisaanpassing.

Natriuminhoud kan met dertig persent verlaag word sonder om die aanvaarbaarheid van die meeste tuisvoorbereide geregte noemenswaardig te verminder. Dit is egter nodig om die sout-interaksie met ander sintuiglike komponente, sowel as die media waarin die natrium voorkom, in aanmerking te neem wanneer aanbevelings ten opsigte van natriumbeperkings gemaak word.

\section{- Ms M Malherbe}

PO Box 82, Kroonstad, 9500

\section{- Dr CM Walsh}

Department of Human Nutrition, University of the Free State, Bloemfontein

\section{- Dr CA van der Merwe}

Institutional Research,

Technikon Free State, Bloemfontein

Financial support: The National Research Foundation (NRF) supported the funding of the study.

\section{INTRODUCTION}

Urbanisation is commonly associated with a shift from the traditional eating pattern to a more westernised lifestyle and diet (Drewnowski \& Popkin, 1997; Popkin \& Doak, 1998; Walker, 1995). As part of this nutrition transition, an increase in the intake of fat, animal protein, sugar and salt has occurred (Walker, 1995). As a result, diseases of lifestyle such as obesity, heart disease, Type 2 diabetes mellitus, certain cancers and hypertension have become common in developing communities (Freudenheim, 1991). In South Africa, urbanisation is taking place at a rapid rate, especially among the black population (Walker, 1995). Although hypertension in rural Africans is relatively low (5-8\%), it is common amongst black urbanised South Africans (Walker, 1995; Walker \& Charlton, 2001), especially those that are Sesotho-speaking (Mollentze et al, 1995). In the black population hypertension occurs at a younger age than in the white population (Isaacson et al, 1989) and prevalence of hypertension tends to be higher in women than in men (Walker, 1995). In urban blacks hypertension has the second highest mortality rate of lifestyle-related diseases, with death among blacks due to hypertension being more than double than among whites (Bradshaw et al, 1995; Walker, 1995).

In an effort to address the problem of hypertension, the reduction of salt intake is recommended for the general public (Witschi et al, 1985; Lang et al, 1985; Walker, 1995). Only $115 \mathrm{mg}$ sodium is necessary per day to maintain sodium balance (Fregly \& Fregly, 1982:14; Mattes \& Donelly, 1991; Robinson et al, $1989: 141)$. An intake of six grams or less of salt (2 $400 \mathrm{mg}$ sodium) is recommended (Norton \& Noble, 1991) based on the potential role of sodium in the development of hypertensive disease later in life (Mahan \& Arlin, 1992:146). Sodium intake exceeds recommended levels in almost all age and gender groups (Mahan \& Arlin, 1992:283). Studies indicate that the average intake is between $5,5 \mathrm{~g}$ and $17,5 \mathrm{~g}$ salt 
per day (Robinson et al, 1989:142; Norton \& Noble, 1991). In both black and white South Africans salt intake is about $10 \mathrm{~g}$ per day (Walker, 1995).

Low-sodium diets are poorly complied with, as they are often considered tasteless and bland (KrisEtherson et al, 1982). Much of the salt that individuals and manufacturers place in foods is present because people "like" the taste of salty food better than the taste of the same food without salt (Bourne et al, 1993). Furthermore, salt is consumed in such large quantities because it is present in so many foods, especially processed foods, and is difficult to avoid (Beauchamp et al, 1982; Kapoor, 1995:159). Consumption data indicate that 35 to 41 percent of salt is added during food preparation and up to 10 percent is added as table salt (Simone et al, 1995).

Although little is really known about the reason for the preference for salty food, the first step in reducing salt intake is to understand sensory responses to salt (Beauchamp et al, 1982). These sensory responses include taste adaptation to a certain sodium concentration (Bertino et al, 1982a; Bartoshuk, 1980:87; Bartoshuk, 1978; Lawless \& Heymann, 1998:44), sodium interaction with other food components (Kroeze, 1990:48,49) and the inhibitory or masking interaction in mixtures of different tastes (Simone et al, 1995; Mattes, 1987:133). The aim of this study was to determine to which degree the salt content of homeprepared foods (varying in terms of sodium content, complexity and texture) may be decreased without significantly affecting acceptability and salt perception.

\section{MATERIALS AND METHODS}

\section{Methods}

Sensory evaluation methods were used to assess the difference in acceptability and salt perception of both simple and complex dishes over three ranges of sodium concentrations (full recipe; approximately onethird sodium reduction; and approximately two-thirds sodium reduction).

\section{Materials}

Four dishes were selected based on the following criteria: inclusion of dishes regularly consumed by the target market; inclusion of both simple and complex dishes; recipes suited to adaptation in respect of sodium content; and recipes representative of different textures. The dishes included were mashed potatoes (a simple dish with a smooth texture, Table 1), crumbed porridge (a simple dish with a coarse texture, Table 2), vegetable soup (a complex dish with a smooth texture, Table 3 ) and beef stew (a complex dish with a coarse texture, Table 4). For each of these, two low-sodium counterparts were developed. Reducing or omitting the salt added to the recipe adjusted the sodium content of the dishes. No additional flavourings, herbs or spices were added to enhance the flavour.
Sodium content of recipes was estimated using the MRC Food Composition Tables (Langenhoven et al, 1991) (Table 5) and validated by determining the actual sodium content in the adapted dishes using standardised chemical analysis (Adrian et al, 1996:497) (Table 6). The results showed a highly significant correlation.

\section{Experimental layout}

Subjects Since a reduction in the habitual use of salt is directed at the public at large, the target market was the general South African consumer. For this reason a sample chosen according to the distribution of blacks and whites in the Free State province (Statistics South Africa, 1996) (N=58) were included. Three age groups (group one $=17$ to 30 years, group two $=30$ to 50 years and group three $=50^{+}$years) were included (Table 7).

Procedure Consumer sensory evaluation was undertaken according to accepted procedures as described by Stone and Sidel (1993:75). Consumers rated food items in evaluation venues that comply with the requirements set by Lawless and Heymann (1998:85).

Acceptability was evaluated according to a nine-point Hedonic scale, ranging from 9 (dislike extremely) to 1 (like extremely). Salt perception was rated using a numerical rating 5-point line scale, ranging from 1 (not salty at all) to 5 (too salty, no longer tasty).

The study consisted of a series of twelve separate evaluation sessions. The same procedure was followed for each session. The evaluation sessions were scheduled for the late morning and the midafternoon. When the consumers arrived at the evaluation venues, they were presented with the test instructions and asked to complete a short sociodemographic questionnaire, which included questions about food preparation and the addition of salt at the table.

Each panellist evaluated two dishes, both served in terms of the three sodium variations, per evaluation session. The exact procedure was repeated the following day. Between the evaluation of each sample, water was used for the cleansing of the palate, and between the evaluations of each dish a break of fifteen to twenty minutes was taken. Each sample was evaluated for both acceptability and salt perception. Samples were presented in transparent plastic containers on white trays and consisted of more or less two mouthfuls $( \pm 30 \mathrm{~g})$, served at serving temperature $\left(50-55^{\circ} \mathrm{C}\right.$ for porridge, $60-65^{\circ} \mathrm{C}$ for mashed potatoes, $67-71^{\circ} \mathrm{C}$ for beef stew, and $61-64^{\circ} \mathrm{C}$ for vegetable soup). The original and the two low-sodium variations were served to panellists simultaneously in random order. Samples were coded by means of three digital codes, in order to eliminate any assumption in respect of the order of the samples. 
TABLE 1:

RECIPE OF SIMPLE DISH WITH SMOOTH TEXTURE (MASHED POTATOES)

\begin{tabular}{|l|c|c|c|}
\hline \multicolumn{2}{|c|}{ Normal recipe } & $\begin{array}{c}\text { Approximately } \\
\mathbf{1 / 3} \text { reduction }\end{array}$ & $\begin{array}{c}\text { Approximately } \\
\text { 2/3 reduction }\end{array}$ \\
\hline Ingredients & Amount used (g) & Amount used (g) & Amount used (g) \\
\hline Potatoes & 750 & 750 & 750 \\
\hline Salted Butter & 15,8 & - & - \\
\hline Unsalted Butter & & 15,8 & 15,8 \\
\hline Salt & 2,8 & 2,0 & 0,9 \\
\hline Parsley & 30,8 & 30,8 & 30,8 \\
\hline Milk & 120 & 120 & 120 \\
\hline
\end{tabular}

TABLE 2:

RECIPE OF SIMPLE DISH WITH COARSE TEXTURE (PORRIDGE I KRUMMELPAP)

\begin{tabular}{|l|c|c|c|}
\hline \multicolumn{2}{|c|}{ Normal recipe } & $\begin{array}{c}\text { Approximately } \\
\mathbf{1 / 3} \text { reduction }\end{array}$ & $\begin{array}{c}\text { Approximately } \\
\text { 2/3 reduction }\end{array}$ \\
\hline Ingredients & Amount used (g) & Amount used (g) & Amount used (g) \\
\hline Water & 375 & 375 & 375 \\
\hline Salt & 5,6 & 3,5 & 1,5 \\
\hline Mealie meal & 300 & 300 & 300 \\
\hline
\end{tabular}

TABLE 3: $\quad$ RECIPE OF COMPLEX DISH WITH SMOOTH TEXTURE (VEGETABLE SOUP)

\begin{tabular}{|c|c|c|c|}
\hline \multicolumn{2}{|c|}{ Normal recipe } & \multirow{2}{*}{$\begin{array}{c}\text { Approximately } \\
1 / 3 \text { reduction } \\
\text { Amount used }(g)\end{array}$} & \multirow{2}{*}{$\begin{array}{c}\text { Approximately } \\
2 / 3 \text { reduction } \\
\text { Amount used }(g)\end{array}$} \\
\hline Ingredients & Amount used (g) & & \\
\hline Onion & 125 & 125 & 125 \\
\hline Butter & 60 & 60 & 60 \\
\hline Carrots & 55 & 55 & 55 \\
\hline Celery & 55 & 55 & 55 \\
\hline Potato & 125 & 125 & 125 \\
\hline Turnip & 125 & 125 & 125 \\
\hline Tomatoes & 375 & 375 & 375 \\
\hline Water & 1000 & 1000 & 1000 \\
\hline Salt & 11,2 & 7,0 & 2,5 \\
\hline Pepper & 1,5 & 1,5 & 1,5 \\
\hline Parsley & 5,25 & 5,25 & 5,25 \\
\hline
\end{tabular}

\section{Statistical analysis}

The same fifty-eight subjects were used at each of the twelve level combinations. This prohibited the use of the standard three-way factor Analysis of Variance (ANOVA) and necessitated a three-way repeated measures ANOVA, which was performed with the aid of both BMDP and SAS packages. Paired-difference t-tests were applied to determine significance of differences in means.

\section{RESULTS AND DISCUSSION}

Use of salt

The results obtained from the socio-demographic questionnaire (Table 8 ) indicated that $18 \%$ of the sampled consumers used more salt in food preparation than recommended by the recipe. In addition, $77 \%$ added salt to food at the table. The majority, however, did not consider themselves to be high salt users $(90 \%)$. 
TABLE 4: RECIPE OF COMPLEX DISH WITH COARSE TEXTURE (BEEF STEW)

\begin{tabular}{|l|c|c|c|}
\hline \multicolumn{2}{|c|}{ Normal recipe } & $\begin{array}{c}\text { Approximately } \\
1 / 3 \text { reduction }\end{array}$ & $\begin{array}{c}\text { Approximately } \\
\text { 2/3 reduction }\end{array}$ \\
\hline Ingredients & Amount used (g) & Amount used (g) & 1500 \\
\hline Beef cubes & 1500 & 1500 & 125 \\
\hline Onion & 125 & 125 & 35 \\
\hline Butter & 35 & 35 & 2 \\
\hline Salt & 11,2 & 5,0 & 1,5 \\
\hline Pepper & 1,5 & 1,5 & 1,5 \\
\hline Bay leaf & 0 ne & 0 ne & 1050 \\
\hline Dried thyme & 1,5 & 1,5 & 300 \\
\hline Water & 1050 & 1050 & 400 \\
\hline Carrots & 300 & 300 & 125 \\
\hline Potatoes & 400 & 400 & 30 \\
\hline Onions & 125 & 125 & 5,25 \\
\hline Flour & 30 & 30 & 375 \\
\hline Parsley & 5,25 & 5,25 & 55 \\
\hline Tomato & 375 & 375 & 55 \\
\hline Celery & 55 & & \\
\hline
\end{tabular}

TABLE 5: SODIUM CONTENT OF DISHES AS OBTAINED FROM THE COMPOSITION TABLES

\begin{tabular}{|c|c|c|c|}
\hline Food item & Sodium per dish (mg) & $\begin{array}{c}\text { Sodium reduction } \\
(\mathrm{mg})\end{array}$ & $\begin{array}{c}\text { Sodium reduction } \\
(\%)\end{array}$ \\
\hline \multicolumn{4}{|c|}{ Smooth texture, simple dish } \\
\hline$A=$ normal & 1331,88 & & \\
\hline $\mathrm{B}=1 / 3$ reduction & 884,16 & 447,72 & 33,62 \\
\hline$C=2 / 3$ reduction & 457,66 & 874,22 & 65,64 \\
\hline \multicolumn{4}{|c|}{ Smooth texture, complex dish } \\
\hline$A=$ normal & 5044,24 & & \\
\hline$B=1 / 3$ reduction & 3412,54 & 1631,70 & 32,35 \\
\hline$C=2 / 3$ reduction & 1664,29 & 3379,95 & 67,01 \\
\hline \multicolumn{4}{|c|}{ Coarse texture, simple dish } \\
\hline$A=$ normal & 2181,60 & & \\
\hline$B=1 / 3$ reduction & 1365,75 & 815,85 & 37,40 \\
\hline$C=2 / 3$ reduction & 588,75 & 1592,85 & 73,01 \\
\hline \multicolumn{4}{|c|}{ Coarse texture, complex dish } \\
\hline$A=$ normal & 5627,60 & & \\
\hline$B=1 / 3$ reduction & 3618,90 & 2008,70 & 35,69 \\
\hline $\mathrm{C}=2 / 3$ reduction & 2053.40 & 3574,20 & 63,50 \\
\hline
\end{tabular}


TABLE 6:

SODIUM CONTENT OF DISHES AS DETERMINED BY STANDARDIZED CHEMICAL ANALYSIS

\begin{tabular}{|c|c|c|c|}
\hline Food item & $\begin{array}{l}\text { Sodium per dish } \\
(\mathrm{mg})\end{array}$ & $\begin{array}{l}\text { Sodium reduction } \\
\text { (mg) }\end{array}$ & $\begin{array}{l}\text { Sodium reduction } \\
\text { (\%) }\end{array}$ \\
\hline \multicolumn{4}{|c|}{ Smooth texture, simple dish } \\
\hline$A=$ normal & 1326,00 & & \\
\hline $\mathrm{B}=1 / 3$ reduction & 850,00 & 476,00 & 35,90 \\
\hline $\mathrm{C}=2 / 3$ reduction & 399,5 & 926,50 & 69,87 \\
\hline \multicolumn{4}{|c|}{ Smooth texture, complex dish } \\
\hline$A=$ normal & 4971,20 & & \\
\hline$B=1 / 3$ reduction & 3346,00 & 1625,20 & 32,70 \\
\hline $\mathrm{C}=2 / 3$ reduction & 1596,52 & A-C $\quad 3374,68$ & 67,88 \\
\hline \multicolumn{4}{|c|}{ Coarse texture, simple dish } \\
\hline $\mathrm{A}=$ normal & 2011,02 & & \\
\hline $\mathrm{B}=1 / 3$ reduction & 1408,44 & 602,58 & 29,96 \\
\hline $\mathrm{C}=2 / 3$ reduction & 730,92 & 1280,0 & 63,65 \\
\hline \multicolumn{4}{|c|}{ Coarse texture, complex dish } \\
\hline$A=$ normal & 5574,00 & & \\
\hline $\mathrm{B}=1 / 3$ reduction & 3758,60 & 1815,4 & 32,57 \\
\hline $\mathrm{C}=2 / 3$ reduction & 1950,90 & A-C 3623,10 & 65,00 \\
\hline
\end{tabular}

TABLE 7:

PANEL COMPOSITION (N=60)

\begin{tabular}{|l|c|c|c|c|}
\hline \multirow{2}{*}{$\begin{array}{c}\text { Population and gender } \\
\text { Age groups (years) }\end{array}$} & \multicolumn{2}{|c|}{ Population group } & \multicolumn{2}{c|}{ Gender } \\
\cline { 2 - 5 } & Black (N=51) & White (N=9) & Male (N=30) & Female (N=30) \\
\hline Group 1:17 - 30: & 22 & 4 & 13 & 13 \\
\hline Group 2:31-50 & 18 & 3 & 11 & 10 \\
\hline Group 3:50+ & 11 & 2 & 6 & 7 \\
\hline
\end{tabular}

It is believed that high salt ingestion is a consequence of habits learned during development (Bertino et al, 1982b:148). Thus, persons that habitually follow such a diet will eventually require a higher sodium concentration for a specific product to be acceptable.

\section{Acceptability}

Table 9 shows the results of the paired-difference ttests with regard to the sodium concentration on acceptability ratings.

A one-third reduction in sodium content did not significantly affect the acceptability of the two complex dishes regardless of texture. Mean acceptability ratings of the beef stew (complex and coarse) and the vegetable soup (complex and smooth) remained un- changed ( $p=0,470$ and $p=0,592$ respectively). When mixtures are developed from substances with different taste qualities, such as in the complex dishes where a number of ingredients are included, salt evokes more than one taste quality (Mattes, 1987:133, Bertino et al, 1982b:1140). These other tastes evoked by salt may mask the one-third sodium reduction. Thus, dish complexity plays an important role in acceptability. In addition, Kroeze (1990:48) suggests that partial adaptation (which occurs because of the complexity of the medium in which the sodium concentration is presented and gradually changes as chewing proceeds) contributes to the masking effect brought about by other tastes evoked by salt in mixtures with different taste qualities. Decrease in acceptability is prevented when there is a continuous perception of the different tastes in the dish, which masks the moderate sodium reduction. 
TABLE 8: DEMOGRAPHIC INFORMATION OF THE CONSUMER PANEL

\begin{tabular}{|c|c|c|c|}
\hline \multicolumn{2}{|c|}{ Category } & \multirow{2}{*}{$\begin{array}{c}\mathbf{N}=58 \\
26\end{array}$} & \multirow{2}{*}{$\begin{array}{c}\% \\
44,8\end{array}$} \\
\hline Age (years) & $17-30$ & & \\
\hline & $31-50$ & 20 & 34,5 \\
\hline & $50^{+}$ & 12 & 20,7 \\
\hline \multirow[t]{2}{*}{ Panel members } & White & 8 & 13,8 \\
\hline & Black & 50 & 86,2 \\
\hline \multirow[t]{2}{*}{ Prepares own food } & Yes & 34 & 59,6 \\
\hline & No & 24 & 41,4 \\
\hline \multirow{4}{*}{$\begin{array}{l}\text { Prepares own food }(\mathrm{N}=34) \text {, salt } \\
\text { added during food preparation }\end{array}$} & According to recipe & 23 & 67,6 \\
\hline & More than recipe & 6 & 17,6 \\
\hline & Less than recipe & 4 & 11,8 \\
\hline & Adds no salt & 1 & 2,9 \\
\hline \multirow[t]{3}{*}{ Salt added at table $(\mathrm{N}=58)$} & No salt added & 14 & 24,1 \\
\hline & Habitually, before tasting the food & 12 & 20,7 \\
\hline & After tasting the food & 32 & 55,2 \\
\hline \multirow[t]{3}{*}{ View of themselves as salt users } & High & 6 & 10,3 \\
\hline & Medium & 39 & 67,2 \\
\hline & Low & 13 & 22,4 \\
\hline
\end{tabular}

There may be a further advantage of partial adaptation. McBurney et al (as cited by Kroeze, 1990:49) showed that this partial adaptation leads to the loss of absolute sensitivity (the sensitivity to a specific taste or one of the basic tastes, often associated with a specific dish), but in turn increases differential sensitivity (the sensitivity to all the tastes - the most prevalent/main taste in combination with the secondary tastes - present in a dish).

In contrast to the mashed potatoes (simple dish with a smooth texture), the results indicate that the acceptability ratings of the crumbed porridge (simple dish with a coarse texture) remained the same for the full recipe as well as for the one-third sodium reduction. A significant decrease in acceptability occurred when the sodium content of the mashed potatoes was decreased by a third $(p \leq 0,0001)$. These findings support data from other studies (Kroeze, 1990:41) and indicate that the way food feels in the mouth is associated with texture. Thus, dish texture also plays an important role in the acceptability of different sodium concentrations in dishes, although to a lesser degree than complexity.

Acceptability (independent of complexity or texture) decreased significantly in three of the four dishes with more than thirty-percent reduction in sodium content. This may be explained by an important effect of adap- tation to salt on taste - that is, concentrations below the adapting concentration evoke a bland taste that increases in intensity as the salt concentration decreases (Beauchamp et al, 1990).

\section{Salt perception}

Table 10 shows the results of the paired-difference ttests with regard to the sodium concentration on the perception of saltiness ratings.

In contrast to the two-thirds reduction, the moderate reduction in sodium concentration in the vegetable soup (complex dish with a smooth texture) did not affect perception of saltiness significantly $(p=0,140)$. In other dish combinations, however, salt perception decreased significantly with a one-third reduction. These results suggest that the concentration of sodium alone does not determine the perception of saltiness in food systems.

A significant decrease in salt perception can be observed (Table 10) with sodium reduction in both the simple dishes (with either smooth [ $p \leq 0,0001]$ or coarse $[p \leq 0,0001]$ texture) used in this study. As with partial adaptation, cross-adaptation occurs because of the complexity of the medium in which the sodium concentration is presented. Simple dishes such as mashed potatoes and crumbed porridge (which dis- 
TABLE 9: EFFECT OF SODIUM CONCENTRATION ON ACCEPTABILITY RATINGS

\begin{tabular}{|c|c|c|c|}
\hline Food item & Mean acceptability (a) & $\begin{array}{c}\text { Differences } \\
\text { in concentrations }\end{array}$ & p-value \\
\hline \multicolumn{4}{|c|}{ Mashed potatoes (Simple dish, smooth texture) } \\
\hline$A=$ normal & 7,35 & & \\
\hline $\mathrm{B}=1 / 3$ reduction & 5,72 & $A-B(b)$ & 0,0001 \\
\hline $\mathrm{C}=2 / 3$ reduction & 5,25 & $A-C(b)$ & 00001 \\
\hline \multicolumn{4}{|c|}{ Vegetable soup (Complex dish, smooth texture) } \\
\hline$A=$ normal & 5,51 & & \\
\hline $\mathrm{B}=1 / 3$ reduction & 5,68 & $A-B(c)$ & 0,592 \\
\hline $\mathrm{C}=2 / 3$ reduction & 4,59 & $A-C(b)$ & 0,019 \\
\hline \multicolumn{4}{|c|}{ Crumbed porridge (Simple dish, coarse texture) } \\
\hline$A=$ normal & 7,03 & & \\
\hline$B=1 / 3$ reduction & 7,43 & $A-B(c)$ & 0,138 \\
\hline $\mathrm{C}=2 / 3$ reduction & 6,35 & $A-C(c)$ & 0,062 \\
\hline \multicolumn{4}{|c|}{ Beef stew (Complex dish, coarse texture) } \\
\hline$A=$ normal & 6,40 & & \\
\hline $\mathrm{B}=1 / 3$ reduction & 6,15 & $A-B(c)$ & 0,470 \\
\hline $\mathrm{C}=2 / 3$ reduction & 4,54 & $A-C(b)$ & 0,0001 \\
\hline
\end{tabular}

(a) Scale 1 to 9: 9 = Like extremely; 1 = Dislike extremely

(b) Significantly different at $95 \%$ level

(c) Not significant

play only one or similar taste qualities in one dish) tend to display a higher level of cross-adaptation than complex dishes (Kroeze, 1990:50).

It is possible that the food used as carrier also determines perceived saltiness. In dishes with normal and one-third sodium reduction content ( $A$ and $B)$, where a main carrier was present (such as the beef in beef stew, the potato in mashed potatoes, and the porridge in crumbed porridge) the salt perception ratings were lower than for the dish (vegetable soup) where a number of ingredients acted as carriers of sodium.

Bertino et al (1982a) have reported differences in perceived saltiness of dishes with a solid composition compared to dishes with a liquid composition. Specifically, the concentration of salt that produced maximum pleasantness was higher in solid foods than in liquid foods such as soup. This could also explain the higher perception of saltiness in the vegetable soup with a reduced sodium concentration compared to the other dishes with a more solid composition used in this study.

Although it is necessary to consider salt interaction with sensory components when reducing the sodium content of dishes, this study indicates that sodium content can be reduced by about thirty percent, with- out significantly changing salt perception in those complex dishes where a main carrier is not present but where all ingredients together contribute to the taste. We propose that perceived saltiness also depends on the medium in which sodium is presented and not only on the sodium concentration.

\section{CONCLUSION}

It can be concluded that it is possible to reduce the sodium content in dishes with a complex composition by about thirty percent, without significantly changing acceptability. Possible reasons include the masking effect that takes place within complex dishes with reduced sodium content, partial adaptation, as well as the decreased absolute sensitivity and increased differential sensitivity. In simple dishes where there is a lack of substances with different taste qualities, a course texture is more acceptable than a smooth texture when sodium concentration is decreased.

Although a reduction of approximately one third in sodium content did not significantly affect salt perception in the complex dishes where no main ingredient was present as a carrier, the salt perception did decrease significantly in other dish combinations where a single carrier was present. Thus, in contrast to ac- 
TABLE 10: $\quad$ EFFECT OF SODIUM CONCENTRATION ON SALT PERCEPTION RATINGS

\begin{tabular}{|c|c|c|c|}
\hline Food item & $\begin{array}{c}\text { Mean salt } \\
\text { Perception (a) }\end{array}$ & $\begin{array}{c}\text { Differences } \\
\text { in concentrations }\end{array}$ & p-value \\
\hline \multicolumn{4}{|c|}{ Mashed potatoes (Simple dish, smooth texture) } \\
\hline$A=$ normal & 2,55 & & \\
\hline $\mathrm{B}=1 / 3$ reduction & 1,66 & $A-B(b)$ & 0,0001 \\
\hline $\mathrm{C}=2 / 3$ reduction & 1,50 & $A-C(b)$ & 0,0001 \\
\hline \multicolumn{4}{|c|}{ Vegetable soup (Complex dish, smooth texture) } \\
\hline$A=$ normal & 2,50 & & \\
\hline $\mathrm{B}=1 / 3$ reduction & 2,23 & $A-B(c)$ & 0,40 \\
\hline $\mathrm{C}=2 / 3$ reduction & 1,72 & $A-C(b)$ & 0,0001 \\
\hline \multicolumn{4}{|c|}{ Crumbed porridge (Simple dish, coarse texture) } \\
\hline$A=$ normal & 3,33 & & \\
\hline $\mathrm{B}=1 / 3$ reduction & 2,77 & $A-B(b)$ & 0,0001 \\
\hline $\mathrm{C}=2 / 3$ reduction & 1,67 & $A-C(b)$ & 0,0001 \\
\hline \multicolumn{4}{|c|}{ Beef stew (Complex dish, coarse texture) } \\
\hline$A=$ normal & 2,50 & & \\
\hline $\mathrm{B}=1 / 3$ reduction & 1,84 & $A-B(b)$ & 0,0001 \\
\hline $\mathrm{C}=2 / 3$ reduction & 1,55 & $A-C(b)$ & 0,0001 \\
\hline
\end{tabular}

(a) Scale 1 to $5: 5=$ Too salty, no longer tasty; 1 = Tasteless (not salty at all)

(b) Significantly different at $95 \%$ level

(c) Not significant

ceptability, which seems to be influenced largely by dish complexity and to a lesser degree by texture, perceived saltiness seems to depend on the presence of a carrier food, the composition of the food, and cross-adaptation.

\section{RECOMMENDATIONS}

Recommendations to reduce salt intake for the general public form an essential component of general dietary guidelines (Lang et al, 1985). Many proposed dietary changes are difficult to achieve in communities adopting a westernised lifestyle where urbanisation, economic improvement and social mobility are common (Bourne et al, 1993; Drewnowski \& Popkin, 1997; Popkin \& Doak, 1998).

Within this situation, the need exists for practical recommendations that can assist in decreasing sodium intake. The results of this study indicate that a reduction of sodium content is possible by omitting added salt or by decreasing the amount added during food preparation.

As far as acceptability of dishes with moderately reduced sodium content is concerned, complex dishes with a smooth texture such as vegetable soup, or with a coarse texture such as beef stew, are recommended above simple dishes. When simple dishes are ingested, those with a coarse texture (such as porridge) are more acceptable than those with a smooth texture (such as mashed potatoes), in cases where sodium content has been moderately reduced.

When eating, the acceptability of a dish is generally of greater importance than the perception of saltiness. When salt perception is taken into account, however, dishes that are comprised of a number of ingredients with no specific carrier food seem to be rated saltier than dishes with a main carrier, in cases where the sodium content is decreased.

\section{REFERENCES}

ADRIAN, J, RABACHE, M \& FRANGNE, R. 1996. Nutritional Analysis Techniques. In Linden, G. 1996. Analytical Techniques for Foods and Agricultural Products. USA. VCH Publishers.

BARTOSHUK, LM. 1978. The psychophysics of taste. The American Journal of Clinical Nutrition 31(June):1068-1077.

BARTOSHUK, LM. 1980. Sensory analysis of the 
taste of $\mathrm{NaCl}$. In Kare, R, Fergly, MJ \& Bernard, RA. 1980. Biological and behavioral aspects of salt intake. New York. Academic Press.

BEAUCHAMP, GK, BERTINO, M, BURKE, D \& ENGELMAN, K. 1990. Experimental sodium depletion and salt taste in normal human volunteers. The American Journal of Clinical Nutrition 51:881-889.

BEAUCHAMP, GK, BERTINO, M \& MORAN, M. 1982. Sodium regulation: Sensory aspects. Journal of The American Dietetic Association 80(1):40-45. BERTINO, M, BEAUCAMP, GK \& ENGELMAN, MD. 1982a. Long-term reduction in dietary sodium alters the taste of salt. The American Journal of Clinical Nutrition 36:1134-1144.

BERTINO, M, BEAUCHAMP, KE \& KARE, MR. 1982b. Dietary sodium and salt taste. In Fregly, MJ \& Kare, RM. 1982. The role of salt in cardiovascular hypertension. New York. Academic Press.

BOURNE, LT, LANGENHOVEN, ML, STEYN, K, JOOSTE, PL, LAUBSCHER, JA \& VAN DER VYVER, E. 1993. Nutrient intake in the urban African population of the Cape Peninsula, South Africa. The Brisk study. The Central African Journal of Medicine 3(4):238-246.

BRADSHAW, D, BOURNE, D, SCHNEIDER, M \& SAYED, R. 1995. Mortality patterns of chronic diseases of lifestyle in South Africa. In Fourie, J \& Steyn, K. 1995. Chronic diseases of lifestyle in South Africa. MRC Theoretical Report.

DREWNOWSKI, A \& POPKIN, BM. 1997. The Nutrition Transition: New trends in the global diet. Nutrition Reviews 55(2):31 - 43.

FREGLY, MS \& FREGLY, MJ. 1982. The estimates of sodium intake by man. In Fregly, MJ \& Kare, RM. 1982. The role of salt in cardiovascular hypertension. New York. Academic Press.

FREUDENHEIM, JL. 1991. Dietary assessment in nutritional epidemiology. Nutrition, Metabolism and Cardiovascular Disease 1(4):207 - 212.

ISAACSON, C, MILNE,FJ \& VAN NIEKERK, I. 1989. Hypertension in black South Africans - new perspectives on old material. South African Medical Journal 76(7):323-324.

KAPOOR, S. 1995. Professional healthy cooking. New York. John Wiley.

KROEZE, JHA. 1990. The perception of complex taste stimuli. In McBride, RL \& MacFie. 1990. Psychological basis of sensory evaluation. New York. Elsevier Science Publishers.

KRIS-ETHERSON, PM, KISLOFF, L, KASSOUF, RA \& ROGERS, C. 1982. Teaching principles and cost of sodium-restricted diets. Journal of The American Dietetic Association 85(1):55-58.

LANG, CL, WEINBERGER, MH \& MILLER, JZ. 1985.
Dietary counselling results in effective dietary sodium restriction. Journal of The American Dietetic Association 85(4):477-479.

LANGENHOVEN, M, KRUGER, M, GOUWS, E \& FABER, M. 1991. MRC Food Composition Tables. $3^{\text {rd }}$ ed. Parow. Medical Research Council.

LAWLESS, HT \& HEYMANN, H. 1998. Sensory evaluation of food: Principles and practices. $2^{\text {nd }}$ ed. New York. International Thomson Publishing.

MAHAN, LK \& ARLIN, MT. 1992. Food, nutrition and diet therapy. $9^{\text {th }}$ ed. Philadelphia. Saunders.

MATTES, RD. 1987. Assessing salt taste preference and its relationship with dietary sodium intake in humans. In Solms, J, Booth, DA, Pangborn, RM \& Raunhardt, O. 1987. Food Acceptance and Nutrition. London. Academic Press.

MATTES, RD \& DONNELLY, D. 1991. Relative contributions of dietary sodium sources. American Journal of Clinical Nutrition 10(4):383-393.

MOLLENTZE, WF, MOORE, AJ, STEYN, AF, JOUBERT, G, STEYN, K, OOSTHUIZEN, GM \& WEICH, DJV. 1995. Coronary heart disease risk factors in a rural and urban Orange Free State Black population. South African Medical Journal 85(2):9096

NORTON, VP \& NOBLE, JM. 1991. Acceptance of quantity recipes with zero added salt by a military population. Journal of American Dietetic Association 91(3):312-315.

POPKIN, BM \& DOAK, CM. 1998. The obesity epidemic is a worldwide phenomenon. Nutrition Reviews 56(4):106-114.

ROBINSON, CH, LAWLER, MR, CHENOWETH, WL \& GARWICK, AE. 1989. Normal and therapeutic nutrition. $17^{\text {th }}$ ed. New York. McMillan.

SIMONE, O, OWEN, M \& ARMAND, V. 1995. Consumer acceptance of food lower in sodium. Journal of the American Dietetic Association 95(4):447-453.

STATISTICS SOUTH AFRICA. 1996. Census in Brief. Report no 1:03-01-11.

STONE, H \& SIDEL, JL. 1993. Sensory evaluation practices. $2^{\text {nd }}$ ed. San Diego, California. Academic Press.

WALKER, ARP. 1995. Nutrition-related diseases in Southern Africa: With special reference to urban African populations in transition. Nutrition Research 15(7):1053-1094.

WALKER, ARP \& CHARLTON, KE. 2001. Nutrition and aging in Africa: Transitional changes. Nutrition Today 36(1):37-42.

WITSCHI, JC, ELLISON, CR, DONALD, DD, GAYE, LV, SLACK, WV \& STARE, FJ. 1985. Dietary sodium reduction among students: Feasibility and acceptance. The American Dietetic Association 85(7):816821. 